Inger M. Mees*

Copenhagen Business School

Christina Høøck Osorno **

Sandberg Translation Partners, UK
UDK 811.111'342.41:81'355

DOI: 10.4312/linguistica.57.1.211-227

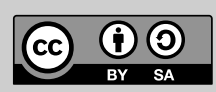

\title{
THE COMPLEXITY OF THE BATH WORDS IN CARDIFF ENGLISH
}

\section{INTRODUCTION}

This paper discusses a small-scale longitudinal empirical study of the choice of vowel phoneme in the BAтH words in Cardiff English. Below we explore the role played by vowel quality, vowel duration and lexical incidence for the choice of TRAP or PALM in this set of lexical items. Two sociolinguistic variables are examined: social class and age/time differentiation. Since Cardiff English exhibits a complex pattern of usage for the BATH set which differs from that of RP and most other varieties of English (section 1.2), it is useful to employ Wells's (1982) standard lexical sets to describe the variation (section 1.1). Recordings were made of 11 speakers (five middle class, six working class) who read a word list and a one-page text (see section 2 for a brief outline of the selection of the informants and the measures used to determine their social class status). Sociolinguistic studies have shown that the use of standard or prestige forms increases in post-adolescence as this is the stage in life when the pressure to conform to the speech norms of the wider society is greatest; notably in their middle years people are likely to use fewer vernacular forms (Holmes 2013: 178-179). Since our recordings represented childhood, early adulthood and middle age, we were able to examine if any potential changes were indeed in the direction of the standard. Section 3 describes the methodology employed to analyse the speech tokens (a combination of instrumental techniques and auditory impressionistic judgment). In section 4 the results are presented and discussed, followed by our conclusions in section 5 .

\subsection{Standard Lexical Sets}

In order to be able to compare the pronunciation of vowels across different varieties of English, Wells (1982) proposed the concept of 'standard lexical sets', which he defined as 'a set of keywords, each of which [...] stands for a large number of words which behave in the same way in respect of the incidence of vowels in different accents' (Wells 1982: 119-120). He termed them 'standard' lexical sets because they were based on the two reference accents RP and General American (GA). One keyword was chosen to represent all the words belonging to a particular set. For instance, the lexical set KIT refers to the pronunciation of the sound which a particular variety employs for those

\footnotetext{
* im.ibc@cbs.dk

** c.h.osorno@hotmail.com
} 
words which have strong /I/ in the two standard accents RP and GA. For our study, the following lexical sets are of importance:

- TRAP comprises those words whose citation form in RP and GA has /æ/; it is nearly always spelt $<$ a $>$, e.g. trap, back.

- START comprises those words whose citation form contains/a:/ in RP and the sequence /ar/ in GA. It is typically spelt $<$ ar $>$, e.g. far, start, but words containing $<$ ear $>$, <er>, and <aar> also occur, e.g. heart, sergeant, bazaar.

- PALM comprises those words whose citation form in RP is /a:/ and /a/ in GA, excluding those words where $<\mathrm{a}>$ is followed by $/ \mathrm{r} /$ in GA (i.e. the START set). This set contains only a handful of common words, usually spelt with $<a>$, e.g. palm, calm, father.

- BATH comprises those words whose citation form contains the vowel /æ/ in GA, but /a:/ in RP. Words in this set are spelt $<\mathrm{a}>$ and occasionally $<\mathrm{au}>$, e.g. dance, bath, laugh. Cardiff English favours /æ/ in some of these words and /a:/ in others; see section 1.2 below.

The quality of the PALM/START vowel is a strong marker of social status in Cardiff, a long front vowel being used by working-class (WC) speakers while the more standardinfluenced central to back vowel is found in the middle class (MC) (Mees 1977: 15, 36-39, Mees 1983: 72; Coupland 1988: 26-27; Wells 1982: 381). When asked about the Cardiff accent, almost all the informants - both WC and MC - mentioned the 'hard /a/s', as in Cardiff Arms Park (the national rugby stadium), which they pronounced with a very front (and sometimes raised) PALM vowel ['ka:dif a:mz 'pa:k]. One of the ten-year-old informants reported: 'If I say ['kæ:dIf], my Mummy 'its me. She says I've got to say ['ka:dif] and talk properly' (Collins/Mees 1990: 96). Interestingly, the quality of the TRAP vowel (more open than in RP and sometimes retracted) does not seem to be subject to the same negative attitudes and is rarely commented on.

Unlike GA, both RP and Cardiff English are non-rhotic accents (Wells 1982: 7576), and therefore PALM and START are identical. For convenience, we shall in the remainder of this paper use PALM as a cover term for both lexical sets.

\subsection{The ватн Set}

The вAтH set constitutes an example of what Wells (1982: 78-79) terms 'lexical-incidental' or 'lexical-distributional variation', i.e. differences in the incidence of phonemes in a specific set of words. Most accents have a TRAP-PALM contrast, and this also holds true for both RP and Cardiff English, e.g. hat - heart, hær - hatt/. (The actual realisation of the vowels may be different; for instance, TRAP is typically more open and retracted in Cardiff, [hat], than in RP, and PALM has a much more fronted (and sometimes raised) articulation, [ha:t].) However, in the lexical set BATH, some varieties of English use TRAP while others favour PALM. In RP, the items belonging to this set have the PALM vowel (see below). By contrast, in many other British regional accents, as well as in other English-speaking varieties such as General American, some or all of the BATH words are pronounced with the TRAP vowel /æ/ (Wells 1982: 133-135). In Cardiff, the situation is complicated for 
three reasons. Firstly, the similar qualities of the PALM and TRAP vowels (both being front open) make it difficult to determine which of the two is selected, at least in the working class (WC). In the middle class (MC), the realisation of PALm is usually similar to RP, [a:]. Secondly, the duration of the TRAP vowel is often variable, adding another difficulty in discriminating the two vowels. Hughes, Trudgill and Watt (2012: 62) observe that southwestern accented speakers in Britain normally use TRAP in many of these words, 'often pronounced with a half-long / $\mathrm{a}^{\mathrm{a}} /$ '; this is also the case in Cardiff English, which has a lot in common with these varieties (Collins/Mees 1990: 87-88, 96). In his study of Cardiff English, Coupland (1988) also draws attention to the 'generally quite long phonetic realizations of even the so-called "short" vowels, which means that the /a/ - /a:/ contrast is not a clear one for some speakers' (Coupland 1988: 28). A further complication is constituted by the 'extremely strong stigmatization of [æ]-type realizations, particularly when lengthened, [which] leads Cardiff speakers to vary both the quality and length of this cluster of sounds when they style-shift' (Coupland 1988: 28-29). Thirdly, contrary to accents like General American, where all the BATH words take TRAP, in Cardiff the individual words making up the set vary (Mees 1983: 75-78; Coupland 1988: 28; Wells 1982: 387). For instance, an item like chance is more likely to take TRAP whereas class favours PALM, but there appears to be no consistent pattern (Wells 1982: 387; Mees 1983: 76; Collins/Mees 1990: 96). To sum up, in Cardiff, three dimensions are involved in the BATH words: vowel quality, vowel length and lexical distribution, resulting in various pronunciations, from long to short, and back to front (Wells 1982: 387; Penhallurick 2007: 156). See Figure 1.

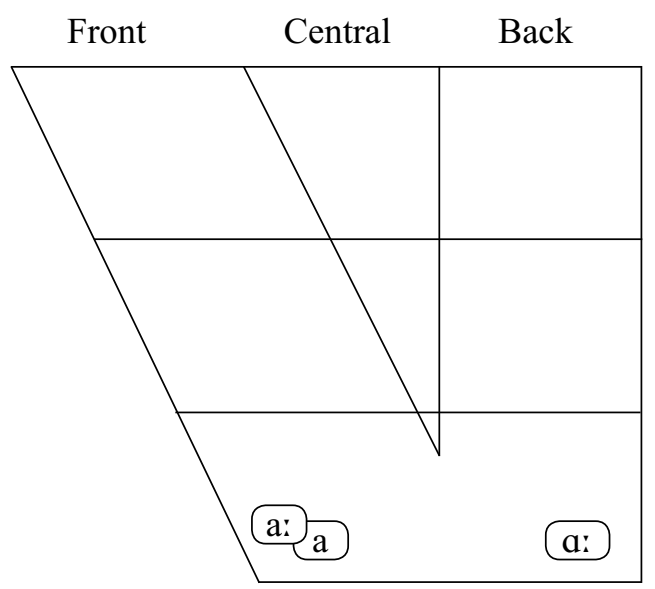

Figure 1: The realisations of the vowels in the BATH words in Cardiff English

The BATH set includes chiefly words where $<\mathrm{a}>$ occurs before consonant clusters containing an initial nasal $/ \mathrm{n} /$ or $/ \mathrm{m} /$ or before the voiceless fricatives $/ \mathrm{f}, \theta$, s/, e.g. chance, laugh, bath, class, and fast (Collins/Mees 2013: 105; Hughes/Trudgill/Watt 2012: 61). However, as Wells (1982) observes, 'sound changes do not always apply to all lexical items which apparently meet their structural description', because 'the lexical diffusion was arrested before all the relevant items had undergone the change' 
(Wells 1982: 100-101). For instance, while RP plant takes PALM, pant is said with TRAP: $\mathrm{RP}$ /pla:nt - pænt/; similarly, grass is pronounced with PALM while gas is said with TRAP: RP /gra:s - gæs/. In the north of England items belonging to BATH generally select the vowel in TRAP (Wells 1982: 353) though a small subset of words, including the high-frequency items half, can't, rather, banana, take PALM (Wells 1982: 135; Hughes/ Trudgill/Watt 2012: 61). As stated above, the situation in Cardiff appears to be much more variable, and we therefore decided to subdivide the BATH words into three phonological contexts to see if this would enable us to detect a more regular pattern. The following contexts were considered:

1. preceding a nasal followed by a consonant, e.g. chance, answer, and demand.

2. preceding a fricative followed by a consonant, e.g. fast, after, and mask.

3. preceding a fricative, e.g. staff, pass, and path.

In this exploratory study we examine the vowel chosen in these three phonological contexts in the speech of a small number of female informants who were recorded at three points in time (see sections 2.1 and 2.2). Because of the difficulties involved in determining whether TRAP Or PALM was selected (section 1.2), it was decided to analyse the vowels using a combination of acoustic measurement and auditory impressionistic judgment.

\section{THE SAMPLE}

\subsection{Selecting the Speakers}

Our study is based on a small number of speakers recorded in Cardiff, the capital of Wales, at three points in time over a period of 34 years $(1977,1990,2011)$. The original 1977 corpus consisted of 80 informants, 56 of whom were re-recorded in 1990 . We selected 11 of the female speakers (five MC and six WC) who participated in both 1977 and 1990. We were able to trace five of these in 2011 (two MC and three WC); hence the 2011 results are clearly less reliable, but it is nevertheless hoped that some initial indications can be discovered. At the time of the first recordings the informants were ten years old. In 1990 they were young adults (aged 23) and in 2011 they had reached mid adulthood (aged 44). The 80 speakers in the original sample were selected from 15 different primary schools in the city of Cardiff. The schools, found with the help of an inspector of the Education Authority and a professor at the Department of Sociology, were located in eight administrative areas which differed with respect to social and economic characteristics.

\subsection{Determining Social Class Status}

A binary social class classification was adopted based on a weighted index of occupation, education and residential area (see Mees/Osorno 2015: 59-61). Father's occupation was used in the 1977 sample but was replaced in 1990 and 2011 by the informants' own occupations. The occupations of the fathers in the 1977 MC group were: economics lecturer, assistant county treasurer, stock control manager, press officer, sales representative. The families lived in typically middle-class districts (e.g. Llanishen, Whitchurch, 
Roath). The fathers' occupations in the WC group were: butcher, lorry driver, car mechanic, coach driver, packer. All the families in this group lived in WC districts such as Splott and Ely. With respect to education, all 1977 MC informants acquired A levels and most proceeded to take a university or teacher training college degree. All ended up in higher-status, white-collar occupations, e.g. accountant, court clerk, and teacher. None of the WC informants gained A levels, though the only girl who obtained O levels in this group went on to take a law degree and worked as an HR and training officer in the hotel industry, and would therefore in 2011 be classified as middle class. The remaining WC speakers worked as waitresses, factory packers, and carers in nursing homes. All continued to live in the districts they were brought up in. This was also to an extent the case for the MC group although there was more geographical mobility in this group since some of the speakers moved to areas outside Cardiff (Aberystwyth, Oxfordshire). For details, see Mees (1983) and Mees/Osorno (2015).

\subsection{The Texts}

In addition to the free speech style obtained in interviews with the authors (IMM in 1977 and 1990, CHO in 2011), recordings were also made of a reading passage and a word list (the last-mentioned only in 1990 and 2011). The reading passage contained seven instances of ватн words while the word list comprised 34 ватн items. For this particular study, the written texts were chosen rather than the free speech excerpts to facilitate the process of data analysis and to ensure a greater degree of comparability of the data. As the 1977 sample did not contain a word list, we used the reading passage to compare the pronunciations of the BATH words at the three points in time; in addition, this passage was employed for the normalisation procedure of the acoustic data (section 3.1.2). The word lists served mainly to illustrate the lexical distribution but were also compared across time (1990 and 2011).

\section{ANALYSES OF THE DATA}

As Labov, Ash and Boberg (2006: 37) observe, '[n]o means of instrumental analysis can be considered reliable without some degree of auditory confirmation.' The acoustic measurements obtained in the present study were therefore supplemented with auditory impressionistic analyses carried out by two trained phoneticians. The two methods are discussed below.

\subsection{Acoustic Analyses}

In general, only a small number of tokens are required in acoustic analyses as compared with auditory analyses. Deterding (1997: 49), who studied 11 monophthongs for 10 speakers, measured approximately 10 occurrences of each of the vowels for each speaker. Fridland (1999) coded fewer than 10 tokens per vowel to represent the mean in her study of the southern shift in Memphis, Tennessee. In his study of the Philadelphia vowel system, Labov analysed between 10 and 20 tokens of a given variable per speaker, though for some of the less frequent vowels, he used down to a single instance per vowel (Labov 
2001: 133). Such a small number of tokens has been accepted in instrumental analyses as these are generally perceived as being more objective than analysis by auditory judgment, which requires a larger number of tokens to reduce misrepresentation due to subjectivity as far as possible (Milroy/Gordon 2003: 151). However, since our corpus contained only a small number of speakers and tokens (seven in the reading passage and 34 in the word list), all vowels were analysed both acoustically and auditorily.

\subsubsection{Vowel Formants}

The acoustic analysis was carried out using the free software program Praat (http://praat. en.softonic.com/). The frequencies of $F_{1}$ and $F_{2}$ for each vowel were measured at the vowel's steady state, as close to the middle of the vowel as possible, at a point estimated to be the least affected by consonantal interference, as recommended by Harrington, Palethorpe and Watson (2000: 67). This procedure was assisted by Praat's inbuilt formant tracker. However, this function is not always exact. Particularly when measuring back vowels, the two first formant tracks may be in close proximity, in some cases so much so that the central peaks of $F_{1}$ and $F_{2}$ may be very difficult to distinguish from one another. This was for instance the case for many of the words pronounced by Angie, whose PALM vowels were very back, approximating cardinal vowel 5. Hence, following Harrington, Palethorpe and Watson (2000: 67), formants sometimes had to be measured manually. The measurements were recorded in Excel spreadsheets, facilitating calculations. Tokens in which the vowel's formant tracks 1 and 2 were not clearly visible were discarded.

\subsubsection{Normalisation Procedure}

A problem when doing acoustic analyses is the difficulty in comparing the data of different speakers. No two vocal tracts are identical, and no two speakers have identical voice qualities, and as a result it may be very difficult to compare the sounds produced by different speakers, particularly when they are of different sexes or ages. In general, both female speakers and children tend to have higher frequencies than male speakers, as their vocal tracts are shorter, which means that their resonance frequencies are higher (Watt/Fabricius 2002: 161; Flynn 2011: 2). By using only female informants, this problem was significantly reduced in the present study. A good normalisation procedure 'eliminates only those differences that are due to physical differences among speakers, but not social differences' (Labov 2001: 159). We employed the modified version (Fabricius/Watt/Johnson 2009) of a relatively new method called the $S$-centroid Vowel Normalisation Procedure, also referred to as the $S$-procedure, which has been proposed by Watt and Fabricius (2002). When tested against other methods, it has shown itself to be one of the most effective methods in allowing comparisons of vowel systems from different speakers (Fabricius/Watt/Johnson 2009: 431; Flynn 2011: 16-17). An obvious advantage of using this procedure is that measurements of only two vowels (FLEECE and TRAP) are needed in addition to the ones that are actually analysed. This is a clear improvement on other vowel-extrinsic normalisation methods, i.e. methods which require employing a number of other vowels (Flynn 2011). 
The vowels measured (FLEECE in addition to PALM and TRAP) were identified from the reading passage. Approximately 10 tokens were selected for each vowel. For an example of the calculation of $S$ for one informant (Judy), see Osorno (2011: 49-50).

The vowel triangles of all 11 speakers in 1990 are shown in Figures 2 and 3, the first showing $\mathrm{F}_{1}$ and $\mathrm{F}_{2}$ in hertz and the second showing them relative to the $S$-centroid in $S$ units. The effectiveness of the normalisation procedure is demonstrated by the overlap of the individual triangles - the greater the overlap, the more successful the normalisation. All names have been changed for the sake of anonymity.

Individual intormants' vowel spaces in $\mathrm{Hz}$

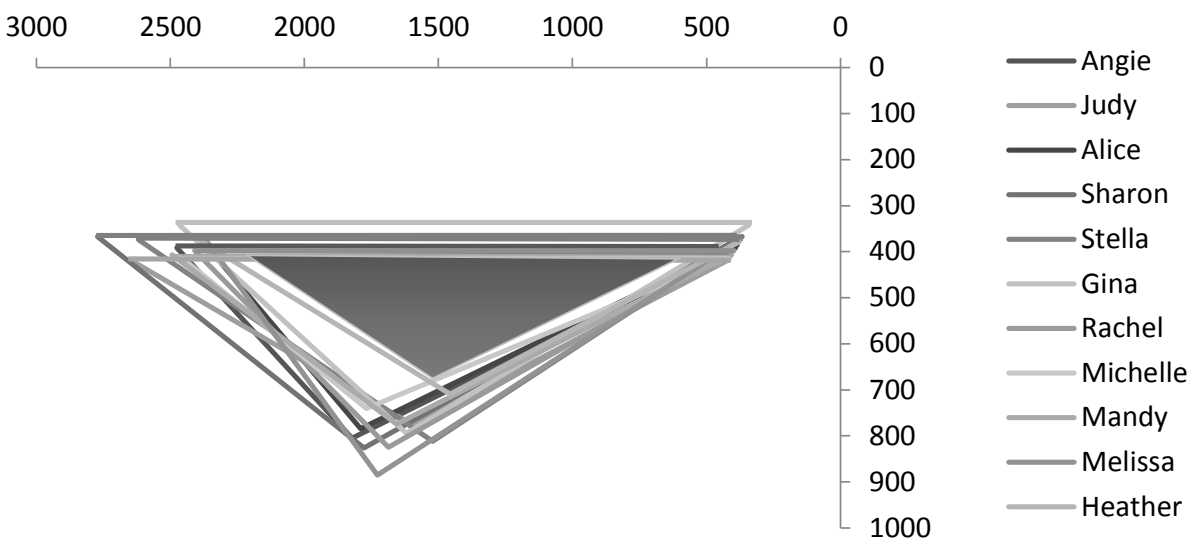

Figure 2: Individual informants' vowel spaces in hertz - prior to normalisation

Individual informants' vowel spaces in S-units

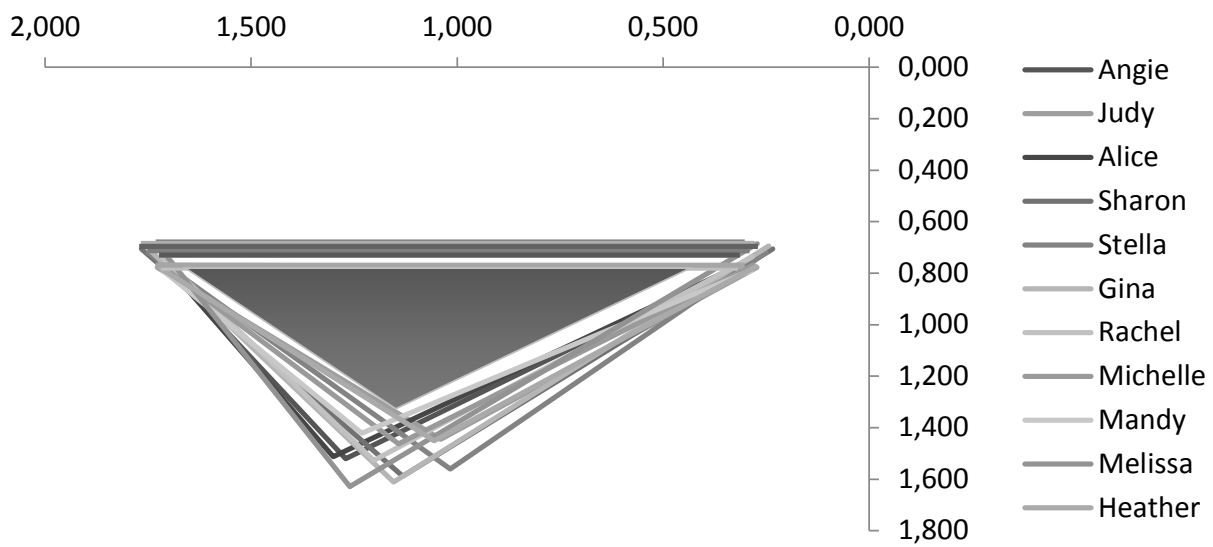

Figure 3: Individual informants' vowel spaces defined relative to the $S$-centroid 
Looking at the informants' vowel spaces before and after normalisation, it can be observed that the procedure has greatly improved the overlap of the triangles, at least at the top. The lack of overlap at the bottom can be argued to be owing to the variability of the TRAP vowel in Cardiff English, some informants having a more front vowel quality than others.

\subsubsection{Vowel Length}

In Cardiff English, the quality of WC TRAP is often similar or identical to that of PALM. As a result, the choice of one or the other vowel in the BATH words can sometimes be recognised by means of length alone (though even this is not a foolproof method as the TRAP vowel is sometimes relatively long; see section 1.2). Therefore, in addition to measuring the formants, the duration of the PALM vowel was also measured. The mean length of the TRAP vowels was not calculated, as the length of this vowel tends to be highly variable (Cruttenden 2014: 98). For instance, unlike any of the other short vowels, when TRAP is followed by a voiced consonant, e.g. bad, it is nearly as long as any of the long vowels (Cruttenden 2014: 120).

The vowels in the PALM set were divided into four categories: word-final position (e.g. far), preceding a voiced (non-nasal) consonant (e.g. hard), preceding a nasal consonant (e.g. farm), preceding a voiceless consonant (e.g. start). It was necessary to take all these categories into consideration as vowel length varies greatly according to its phonological context. It has been found that vowels are fully long when they occur in word-final position or are followed by a voiced consonant, shortened when they occur before a nasal, and shortest before a voiceless consonant (Cruttenden 2014: 101). However, as the items were taken from a reading passage, the words were also affected by the reading rate of the informants, some words being pronounced faster than others regardless of their phonological context because of their position in the reading passage. To compensate for these effects, the different PALM vowels were added up and divided to arrive at an average length. The mean length was made as representative as possible by using words from the four different categories.

The mean length of the PALM vowel was then compared with the length of the vowel in each word from the ватн lexical set. If the vowel in the ватн set was shorter than the mean length of the vowels in the PALM set, it was categorised as a TRAP vowel, and conversely, if it was longer, it was categorised as a PALM vowel.

\subsection{Auditory Impressionistic Analyses}

A critique of instrumental techniques has been that although they can demonstrate fine-grained distinctions, they cannot show whether the many different variants can actually be perceived by listeners (Macaulay 2009: 25; Milroy/Gordon 2003: 150151). To ensure that the different realisations of the Cardiff вAтH words were actually audible to hearers, the acoustic technique was supplemented with an auditory analysis carried out by two trained phoneticians who listened to all the tokens. Since any discrepancy between the judgements of the two raters could in principle be attributed to their perceiving the items in terms of their own usage or their degree of familiarity 
with the accents of the area, it was decided to use two phoneticians who differed in these two respects. Neither was a speaker of Cardiff English, one being one of the authors (IMM), the other a speaker of a different variety of South Wales English. ${ }^{1}$ The first listener used PALM for all BATH words while the second employed TRAP in some of the words.

The two raters listened to 544 instances in the word list (34 items read by 11 informants in 1990 and five in 2011) and 184 in the reading passage. They were asked to state whether they heard the item as TRAP or PALM. In cases of doubt they were instructed to make a choice but to indicate in a separate column by means of a question mark that it had been difficult to determine which of the vowels was used. In the word list there was a lack of correspondence between the judgments in only $2.6 \%$ of the instances, and if the tokens with question marks are excluded, the disagreement was a mere $0.6 \%$. In the reading passage, the discrepancy between the two raters was $1.6 \%(1.1 \%$ if the occurrences with question marks are disregarded). Thus degree of familiarity with the accent and own usage did not appear to lead to different results among the raters. The disagreement between the auditory and the acoustic results also proved to be relatively small. Of the 527 instances in the word list (we left out the 17 tokens where the judgments of the raters were at variance) only $8.9 \%$ of the auditory results differed from the acoustic results, and of the 181 instances in the reading passage (here three tokens were omitted), only $6.1 \%$ differed.

\section{RESULTS}

As detailed in section 3 above, the vowels in the BATH words were analysed using a combination of auditory and acoustic techniques. The results of the two methods did not differ significantly. Nevertheless, in the few cases where there were discrepancies, the auditory results were given precedence over the acoustic results. Below, three dimensions are considered: (1) the quality of the vowels, i.e. their degree of backness, (2) their length (considered in combination with their degree of backness), and (3) their lexical incidence.

\subsection{Vowel Quality}

In terms of vowel quality, it is evident from the results that there is a marked distinction between the $\mathrm{WC}$ and the MC. While the MC informants differentiate clearly between the TRAP and PALM vowels, TRAP being front and PALM back, most of the WC informants appear to have a similar quality for both vowels. Figures 4 and 5 provide typical examples of the realisations of the TRAP and PALM vowels (in non-BATH words) for one $\mathrm{MC}$ and one $\mathrm{WC}$ informant. In addition, the realisation of the vowels selected in the вAтH words is shown. The examples have been taken from the reading passage in the 1990 sample. The axes were reversed so as to represent a traditional vowel diagram, axis (y) on the right showing height, and axis (x) at the top indicating degree of backness.

1 Our sincere thanks to Paul Carley (University of Leicester) for his generous help. 
MC realisations of PALM,

TRAP and BATH

F2/S(F2)

$\begin{array}{llllll}1,600 & 1,400 & 1,200 & 1,000 & 0,800 & 0,600\end{array}$

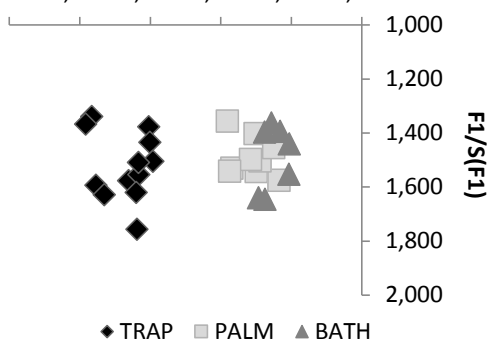

Figure 4: Realisations of PALM, TRAP and the vowels selected in the BATH words in the 1990 reading passage for one MC informant (Angie).
WC realisations of PALM, TRAP and BATH

F2/S(F2)

1,600 1,400 1,200 1,000 0,800 0,600

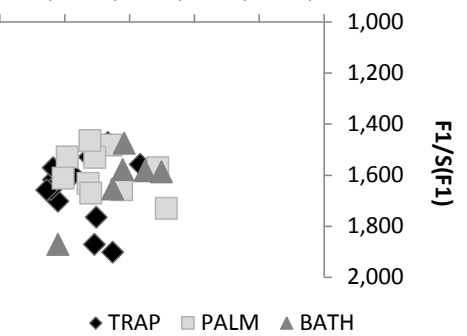

Figure 5: Realisations of PALM, TRAP and the vowels selected in the BATH words in the 1990 reading passage for one WC informant (Mandy).

For the MC informant, the two vowels are clearly separated, and it can be seen that the PALM vowel is selected for the BATH words. For the WC informant, on the other hand, the TRAP and PALM vowels overlap, showing a very similar (front) quality. As the realisations of TRAP and PALM are on the whole front, and the vowel in the BATH words is also front, it can be very difficult to determine which of the two vowels was selected for these words. Whatever the case may be, it is clear that the WC informant has a significantly more front pronunciation of the BATH words than the MC informant. Note that vowel height was not addressed in this study, as it did not appear to have any crucial social significance. To determine whether the informants chose TRAP or PALM for the BATH lexical set, it was therefore necessary to consider the length of the vowel.

\subsection{Vowel Quality Combined with Length}

In RP, PALM is long and TRAP (with some exceptions) is short. As we have seen, in Cardiff English, three representative vowels may be distinguished, namely TRAP, back PALM and front PALM. In Figures 6 and 7, the distribution of the three vowels for the seven BATH words in the reading passage and their development over time from 1977 to 1990 and 2011 is presented for the two social classes.

Figure 6 shows that the MC informants almost always select the back PALM vowel. Only in a few cases do they choose the TRAP vowel, and they never use front PALM. This pattern seems to be relatively stable across time. However, the pattern for the WC informants (Figure 7) is somewhat more varied. In 1977 they select the front PALM vowel in the majority of cases, and choose TRAP for the remaining occurrences. Back PALM is never selected. The distribution in 1990 is very similar to that of 1977 though it can be seen that a very small percentage of back PALM is introduced. Finally, in 2011, the use of the front PALM vowel has been significantly reduced while a 
MC distribution of vowels in the BATH words

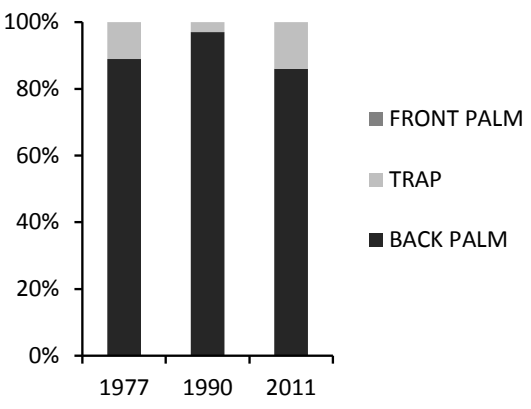

Figure 6: Distribution of the three vowels used for the BATH words in the MC across time. Reading passage.
WC distribution of vowels in the BATH words

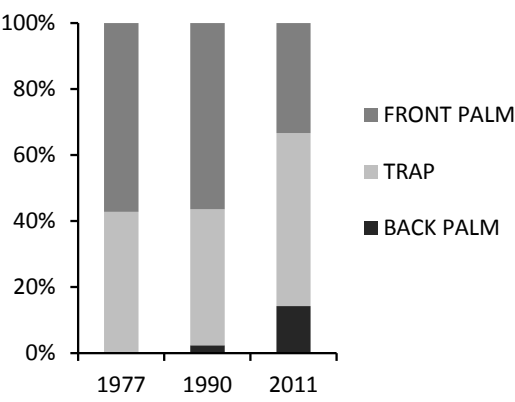

Figure 7: Distribution of the three vowels used for the BATH words in the WC across time. Reading passage.

retracted realisation of PALM has gained ground, as has the use of TRAP, which shows a marked increase and is now the variant selected most frequently. It is noteworthy that the 2011 occurrences of back PALM are found mainly in the speech of the upwardly socially mobile speaker (section 2.2).

The increased use of front PALM by the WC is likely to be the result of age-grading. This is a phenomenon in which speakers 'gradually alter their speech habits as they get older, and where this change is repeated in every generation' (Trudgill 2003: 6). As stated in the introduction, sociolinguistic studies have shown that speakers tend to modify their language in the direction of the prestige norm as they approach middle age as a response to the greater responsibilities at work and at home. Since the speakers use more standard forms in middle age than in childhood or early adulthood, our findings would appear to indicate that back PALM is indeed perceived as the prestige form while front PALM is stigmatised. It is more difficult to determine the status of TRAP. It is used more frequently by the $\mathrm{WC}$ than the $\mathrm{MC}$, which would normally indicate it is less prestigious, but nevertheless it does not appear to have the negative social connotations associated with front PALM; it is rarely commented on by the speech community. Interestingly, however, the degree of acceptability of TRAP appears to depend on the lexical item. We shall examine this in section 4.3 below.

\subsection{Lexical Variation}

Figures 8-11 show the lexical distribution for the 34 items in the word list for the two social classes in 1990 and 2011. As stated earlier, the words have been divided into three categories: (1) pre-nasal plus consonant, (2) pre-fricative plus consonant, and (3) preceding a fricative alone. It should be borne in mind that the results from 2011 are based on only three $\mathrm{WC}$ and two MC informants. This obviously reduces the reliability of the data and makes it difficult to draw any general conclusions. 
Incidence of TRAP and PALM in the BATH words for WC in 1990

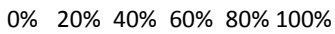

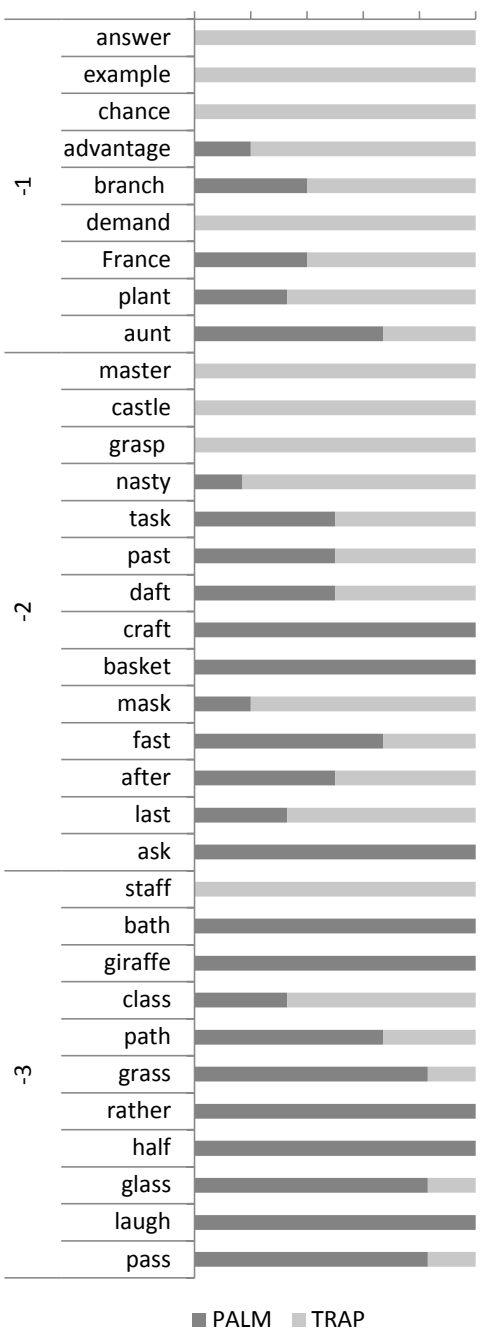

Figure 8: Incidence of TRAP and PALM for the BATH lexical set in the word list for WC in 1990. Three phonological contexts.
Incidence of TRAP and PALM in the BATH words for WC in 2011

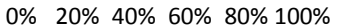

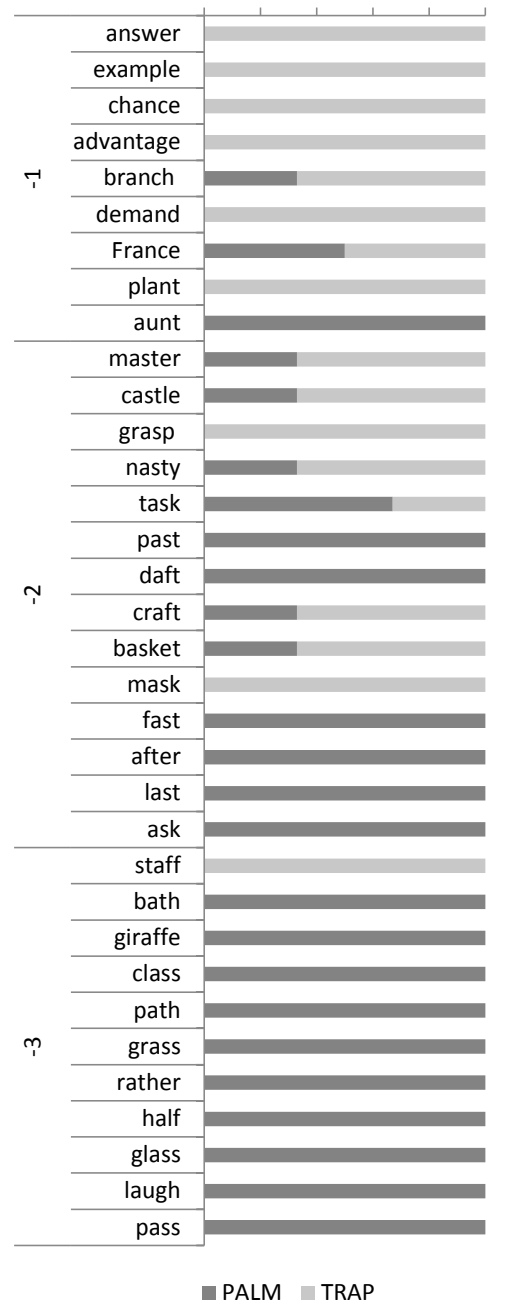

Figure 9: Incidence of TRAP and PALM for the BATH lexical set in the word list for WC in 2011. Three phonological contexts. 
Incidence of TRAP and PALM in the BATH words for MC in 1990

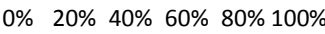

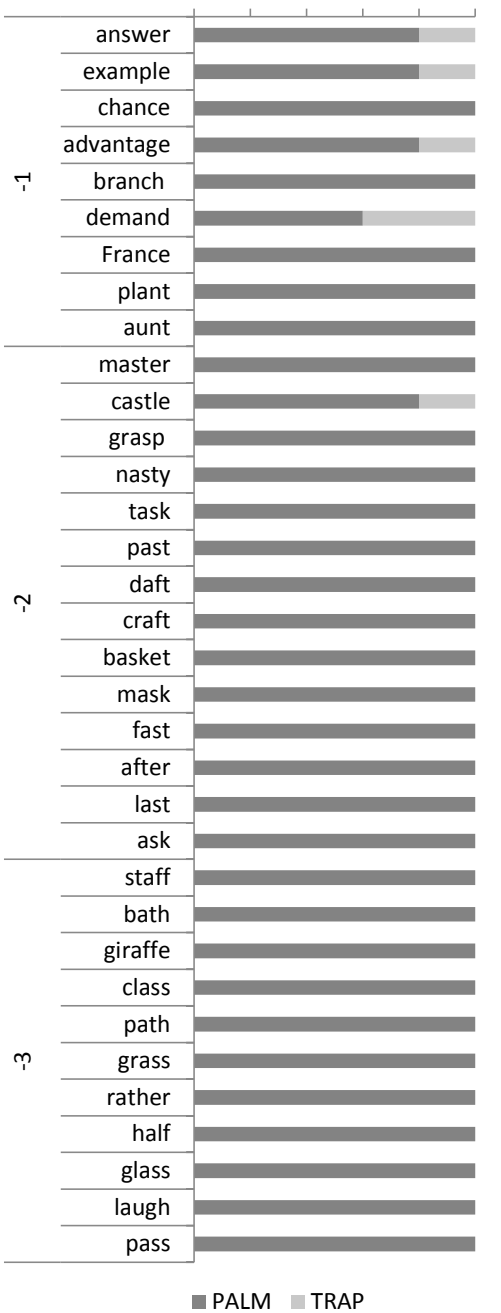

Figure 10: Incidence of TRAP and PALM for the BATH lexical set in the word list for MC in 1990. Three phonological contexts

\section{Incidence of TRAP and PALM in the BATH words for MC in 2011}

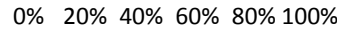

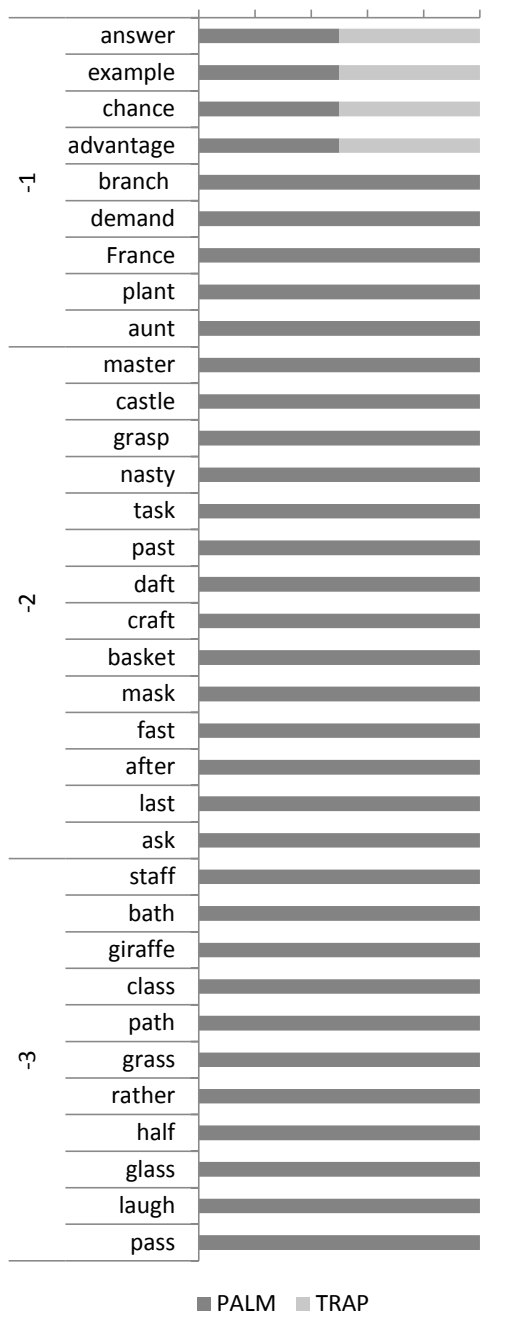

Figure 11: Incidence of TRAP and PALM for the BATH lexical set in the word list for MC in 2011. Three phonological contexts. 
As can be seen from figures 10 and 11, TRAP was rarely used by the MC. When it was selected by this social class it appeared to be overwhelmingly for the words belonging to category 1 . The MC informants never selected TRAP for words in category 3 (either in 1990 or 2011), and the same holds true for category 2, where only a single word (castle) occasionally favoured TRAP, and this only in 1990. By mid-adulthood all MC speakers had switched to PALM for all items in this category as well. The WC speakers also overwhelmingly selected PALM in category 3 (Figures 8 and 9). Although some of the words in this category exhibited a degree of TRAP in 1990, by 2011 all items except for staff had been replaced by PALM. Just as in the MC, speakers from the WC also typically selected the TRAP vowel for words in category 1; only aunt formed a clear exception. For words in category 2 the WC pattern is less clear. Although the informants seemed to favour the TRAP vowel for some of the words, e.g. grasp, for other words such as ask they were more likely to choose PALM. For two of the words, craft and basket, they even change from favouring PALM in 1990 to preferring TRAP in 2011.

In category 1 , the overall tendency seems to be for both WC and MC speakers to increase their use of TRAP in mid adulthood although for the MC this holds true for only a selection of the words; in fact, five of the nine words in this category are 100\% PALM in 2011. However, in the WC, most words have either majority TRAP or $100 \%$ TRAP when the speakers reach middle age.

On the basis of these results, it can be concluded that while the TRAP vowel is a possible choice for the informants for words in category 1, i.e. pre-nasal, it is only accepted for some words in category 2, e.g. castle (both WC and MC), master, grasp and nasty (only WC), and it is accepted for almost no words in category 3 , the exception being staff in the WC. This is different from the north of England, where the use of TRAP is much more widespread and would be used in most of the words included in the list.

\section{CONCLUSION}

The BAтH words in Cardiff English are complex because of the many aspects which have to be taken into consideration, namely (1) lexical distribution, i.e. whether the PALM Or TRAP vowel is selected in the lexical set constituting the BATH words; (2) in cases where the PALM vowel is chosen, whether it has a front or a back realisation, and (3) vowel length. From the results, it is evident that the back PALM vowel is the form favoured by the MC. Only in relatively few instances did the speakers belonging to this class use the TRAP vowel, and then only in some words - in virtually all cases words in which the vowel preceded a nasal plus another consonant. The WC, on the other hand, very rarely used the prestigious back PALM vowel. Instead they seemed to favour the more local forms, TRAP and front PALM. However, across time (notably in middle age), the use of front PALM decreased markedly while, conversely, the use of TRAP and back PALM increased. In this social class, TRAP was also found to occur most frequently in words containing a nasal plus another consonant though it was also selected for a number of the words in which the vowel preceded a fricative plus another consonant. Thus our study has shown that it is useful to undertake a further subdivision of the BATH words on the basis of phonological context. 
Our findings suggest that two types of linguistic variable may be observed for the BATH words in Cardiff. Front PALM, decreasing over time for the WC and never appearing in the speech of the MC, has many similarities in common with the classic stereotype. The TRAP vowel, however, increasing rather than decreasing across time, does not appear to carry negative connotations, though it cannot entirely be regarded as a prestige form either, at least not in the $\mathrm{MC}$, which continues to use relatively few TRAP vowels. In fact, when used in words in which the vowel precedes a fricative, it is clearly perceived as less socially acceptable.

In this exploratory study, we have found indications that the choice of vowel in the BATH words is determined by a combination of factors such as social class, age, lexical and phonological distribution. However, despite the emergence of these patterns, the situation remains somewhat confusing, with notably broad Cardiff speakers showing a variable pattern of alternation between PALM and TRAP. Coupland (1988: 28) observed in the 1980s that 'there is scope for more research into conditioned variation in [long/short] vowels in different lexical sets across different British communities', and even though this to an extent remains true today, we hope our findings have brought us one step closer to clarifying the distribution of this interesting set of lexical items in Cardiff English.

\section{References}

COLLINS, Beverley/Inger M. MEES (1990) "The phonetics of Cardiff English.” In: Nikolas Coupland (ed.), English in Wales: Diversity, Conflict and Change. Clevedon: Multilingual Matters, 87-103.

COLLINS, Beverley/Inger M. MEES (2013) Practical Phonetics and Phonology: A Resource Book for Students. Abingdon: Routledge.

COUPLAND, Nikolas (1988) Dialect in Use: Sociolinguistic Variation in Cardiff English. Cardiff: University of Wales Press.

CRUTTENDEN, Alan (2014) Gimson's Pronunciation of English, 8th edn. Abingdon: Routledge.

DETERDING, David (1997) "The formants of monophthong vowels in standard southern British English pronunciation." Journal of the International Phonetic Association 27, 47-55. http://dx.doi.org/10.1017/S0025100300005417

FABRICIUS Anne/Dominic WATT/Daniel Ezra JOHNSON (2009) “A comparison of three speaker-intrinsic vowel formant frequency normalization algorithms for sociophonetics." Language Variation and Change 21/3, 413-435. http://dx.doi. org/10.1017/S0954394509990160

FLYNN, Nicholas (2011) "Comparing vowel formant normalization procedures." York Papers in Linguistics Series 2/11, 1-28. http://www.york.ac.uk/language/ypl/ ypl2issue11/YPL11_01_Flynn.pdf

FRIDLAND, Valerie (1999) "The southern shift in Memphis, Tennessee." Language Variation and Change 11/3, 267-285. 
HARRINGTON, Jonathan/Sallyanne PALETHORPE/Catherine WATSON (2000) "Monophthongal vowel changes in Received Pronunciation: an acoustic analysis of the Queen's Christmas broadcasts." Journal of the International Phonetic Association 30, 63-78. http://dx.doi.org/10.1017/S0025100300006666

HOLMES, Janet (2013) An Introduction to Sociolinguistics, 4th edn. London: Routledge.

HUGHES, Arthur/Peter TRUDGILL/Dominic WATT (2012) English Accents \& Dialects, 5th edn. London: Hodder Education.

LABOV, William (2001) Principles of Linguistic Change: Volume 2: Social Factors. Malden: MA: Blackwell.

LABOV, William/Sharon ASH/Charles BOBERG (2006) Atlas of North American English: Phonetics, Phonology and Sound Change. Berlin: Mouton de Gruyter.

MACAULAY, Ronald K. S. (2009) Quantitative Methods in Sociolinguistics. Basingstoke: Palgrave Macmillan.

MEES, Inger M. (1977) Language and Social Class in Cardiff: A Survey of the Speech Habits of Schoolchildren. MA diss., University of Leiden.

MEES, Inger M. (1983) The Speech of Cardiff Schoolchildren: A Real Time Study. Doctoral diss., University of Leiden.

MEES, Inger M./Christina Høøck OSORNO (2015) "Cardiff English: A real time study of stability and change between childhood and mid-adulthood." ELOPE 12/2, 5377. http://dx.doi.org/10.4312/elope.12.2.53-77

MILROY, Lesley/Matthew GORDON (2003) Sociolinguistics: Method and Interpretation. Malden: Blackwell.

OSORNO, Christina Høøck (2011) Sociolinguistic Variation and Change in Cardiff English: A Real-time Study of Five Linguistic Variables and their Social Stratification. MA diss., Copenhagen Business School. http://studenttheses.cbs.dk/bitstream/ handle/10417/2887/christina_hoeoeck_osorno.pdf?sequence=1

PENHALLURICK, Robert (2007) "English in Wales." In: David Britain (ed.), Language in the British Isles. Cambridge: Cambridge University Press, 152-170.

TRUDGILL, Peter (2003) A Glossary of Sociolinguistics. Edinburgh: Edinburgh University Press.

WATT, Dominic/Anne FABRICIUS (2002) "Evaluation of a technique for improving the mapping of multiple speakers' vowel spaces in the $\mathrm{F}_{1} \sim \mathrm{F}_{2}$ plane." In: D. Nelson (ed.), Leeds Working Papers in Linguistics and Phonetics 9, 159-173.

WELLS, John C. (1982) Accents of English. 3 vols. Cambridge: Cambridge University Press.

\section{Abstract \\ THE COMPLEXITY OF THE BATH WORDS IN CARDIFF ENGLISH}

This article investigates how a small number of female speakers from Cardiff pronounce items belonging to the lexical set ватн. The data forms a subsample extracted from a longitudinal study on Cardiff English with recordings from 1977, 1990 and 
2011. The BATH set comprises items (e.g. chance, bath) whose citation forms contain the TRAP vowel /æ/ in General American but the PALM vowel/a:/ in British RP. In other accents of English, including Cardiff English, the lexical distribution of the items is often less straightforward, with some items taking PALM while others take TRAP. The situation is particularly complex in Cardiff as the realisations of TRAP and PALM may sound very similar, both having a front vowel quality; furthermore, TRAP may be halflong. Consequently, it can be difficult to determine which of the vowels is selected. We analyse the vowels (both vowel quality and duration) of 11 (five in 2011) working and middle class informants who recorded a reading passage containing seven BATH words at all three points in time. In addition, we study a word list comprising 34 items read by the same speakers in 1990 and 2011. The vowels were subjected to both auditory impressionistic and acoustic analyses. We attempt to establish the social significance attached to the different pronunciations and also to discover if phonological context plays a role for the choice of vowel.

Keywords: BATH words, Cardiff English, vowel quality, vowel length, longitudinal study, acoustic analysis, auditory impressionistic analysis, lexical variation, real-time study

\section{Povzetek}

\section{KOMPLEKSNOST BESED VZORCA »BATH« V CARDIFFSKI ANGLEŠČINI}

Članek ugotavlja, kako nekaj ženskih govork iz Cardiffa izgovarja besede, ki pripadajo leksikalnemu naboru $»$ BATH«. Podatki predstavljajo podvzorec posnetkov iz longitudinalne študije cardifske angleščine, ki so nastali v letih 1977, 1990 in 2011. Leksikalni nabor »BATH« vsebuje besede (npr. chance, bath), ki v standardni ameriški angleščini vsebujejo samoglasnik /æ/, v standardni britanski angleščini pa samoglasnik /a:/. V drugih angleških narečjih, vključno s cardifsko angleščino, je distribucija teh besed pogosto manj enoznačna; tako se nekatere besede izgovarjajo $s$ samoglasnikom /a:/ druge pa s samoglasnikom /æ/. Situacija je še posebej kompleksna v Cardiffu, saj sta uresničitvi obeh samoglasnikov zelo podobni; oba sta sprednja samoglasnika. Poleg tega je samoglasnik /æ/ lahko podaljšan. Zato je težko določiti, kateri samoglasnik je izrečen. Analizirali smo kakovost in dolžino samoglasnikov pri enajstih govorkah (pet leta 2011) delavskega in srednjega razreda, ki so brale besedilo, v katerem je bilo sedem besed iz leksikalnega nabora »BATH«. Poleg tega smo preučili tudi seznam 34 besed, ki so jih prebrale iste govorke v letih 1990 in 2011. Samoglasnike smo analizirali s slušno in akustično metodo. Poskušali smo ugotoviti družbeni pomen različnih izgovarjav, kakor tudi vpliv fonološkega konteksta pri izboru določenega samoglasnika.

Ključne besede: besede iz leksikalnega nabora »BATH«, cardifska angleščina, kakovost samoglasnika, dolžina samoglasnika, akustična analiza, slušna analiza, leksikalna odstopanja, študija v realnem času 